\title{
Children's Homes and Working With Families
}

\author{
Valentina Calcaterra (Corresponding author) \\ Department of Sociology, Università Cattolica, Milan \\ Largo Gemelli 10 - 21013 Milan, Italy \\ Tel: 39-02-6234-3766 E-mail: valentina.calcaterra@unicatt.it
}

Received: February 10, 2014 Accepted: March 14, $2014 \quad$ Published: April 30, 2014

doi:10.5296/ijsw.v1i1.5092

URL: http://dx.doi.org/10.5296/ijsw.v1i1.5092

\begin{abstract}
The article presents the experience and considered reflection of social workers from the social cooperative La Casa davanti al sole, a non-profit organisation which has been managing children's homes and has been providing support to vulnerable families in the north of Italy since 1987.

The daily work of social workers involved in the care of children and young people has raised questions regarding the ethical approach and definition of performance indicators in the areas of child protection and family support. What is the best way to care for a child who has been removed from his or her family? How can the most appropriate care for his or her particular situation be guaranteed? What is the best way to communicate with and relate to the family? These questions have always been at the centre of childcare and give rise to a continuous evaluation and analysis of the role of children's homes in child protection. The methodological awareness presented in the paper is the result of over twenty years of working with children and their families.
\end{abstract}

Keywords: child protection, children's home, participation, parenting skills, care

\section{Introduction}

There is an ongoing debate in Italy on child protection and the need to work with the families of children in care, in order to encourage reunification. Up to the 1970s, children and young people removed from their families were taken to residential institutions. These were centres that catered for up to a hundred young people, usually divided according to age, and which guaranteed residential care that was "equal for all". The insertion of children into institutions was regarded as a "last resort" and a response to deviant behaviour, situations of family abuse or family poverty.

By the early 1980s, greater importance was being given to children's homes; these centres 
accommodate a maximum of ten children and provide a more family-like environment with a closer relationship between staff and children and an individualised plan of care. The primary legal point of reference is Law 184/1983, which regulates cases of removal of children from their families.

In 2001, this law was revised, leading to the definitive closure of the institutions (or their conversion into children's homes) and the enshrining of the right of children to grow up primarily within their own family, or, when not possible, in an alternative family-like environment with a view to future reunification. The 2001 Act confers upon children's homes the task of implementing actions that enable actual processes of change in the disadvantaged circumstances of the children cared for (Gregorio \& Tomisich, 2007; Bastianoni \& Taurino, 2009). This path of reform has promoted a great deal of reflection on the role of carers working in homes and on the need to work with families so that they can recover their parenting skills and be reunited with their children. How can care workers promote processes of change which favour the conditions for reunification? How can they work with the families of the children?

These questions have been at the centre of the working practices of the social workers at the La Casa davanti al sole Social Cooperative. This Cooperative has run three children's homes since 1987 and, over the course of thirty years, has housed and worked with around one hundred children and young people.

This article presents the conclusions of a year-long working group of social workers from the Cooperative. The group was headed up by a university researcher, and was designed to evaluate the work carried out in the children's homes. The team first studied the existing literature in the field of child protection and, subsequently, through focus groups, social workers analysed their own working practices, identifying correlations with or differences from the conclusions provided by research. They focused on the strengths and weaknesses of their own experience of working with children and families and the practices based on the principle of participation.

\section{Working With Children in Care. Some Indications From Research}

To understand how to work with children in care, it is first necessary to understand the position of the families when they experience the removal of their children. Several qualitative studies have addressed this issue at an international level (Fernandez, 1996; Burgheim, 2002; Buckley, 2003; Cameron \& Hoy, 2003; Freymond, 2003; Thomson \& Thorpe, 2003; Harries, 2008; Schofield et al., 2011; Walker, 2011). These studies document the suffering that families undergo following the removal of the child, the elements which aggravate this pain and the consequences. Carers struggle to accept and deal with this suffering because they are often seen as the cause of it.

In Italy there are very few studies that give voice to the families or children who have been removed (Bondioli \& Molinari, 2005; Aglietta et al., 2010; Carletti \& Pellegrini, 2011; Patt, 2011; Belotti et al., 2012). However, they all show how families are not involved in the lives of their children after removal, do not participate in decision-making processes, complain 
about a lack of cooperation with carers and feel pushed out of their children's lives. And the experience of the child is no different. The children complain about not being listened to and being unable to participate in the planning of their own lives, remaining at the mercy of the decisions of the social workers.

National surveys on the situation of children living outside the family also contain elements for concern.

The current Italian social system, characterized by a persistent lack of basic levels of service to ensure the enforceability of civil and social rights and the simultaneous impoverishment, both culturally and of investment in human and financial resources, seriously puts into question "the right of every child to grow up in a family" (CRC Group (Note 1), 2013)

The latest survey on children in care (Ministry of Labour and Social Policy, 2012) shows that 14,781 children and young people live in children's homes, a figure which is virtually unchanged from that of the first survey in 1998. Fifty-three percent of the young people in homes are aged between 14 and 17 . Of the total number of children in care, for at least $43 \%$ it is the second time they have been placed in a children's home, and $63 \%$ are there as a result of a judicial ruling.

The monitoring report of the 3rd National Plan for Childhood (2011) showed an increase in the length of stay for children in homes. The extended period of stay, as well as the high percentage of children in their second experience of living in a children's home, are critical elements which, as noted by the CRC group, highlight the worrying lack of family support processes designed to lead to an effective reunification. However, the removal of the child in Italy is not an end in itself; it is seen as a temporary act of protection, with the ultimate aim of reunification.

These data, as well as research findings, raise the question of how care workers can work with families to promote effective processes of reunification. Again, the indications emerging from the international literature come to our rescue. Research into the Family Decision Making approach (Morris, 2007, 2012) shows that when the family is able to participate in the planning of child protection they respond positively, more effective interventions are implemented, collaboration with social workers increases, and negative situations for the children are reduced. Other significant research shows that when children and their families have a real opportunity to participate in child protection planning at the outset, they feel better and the processes are more effective (Moyers, Farmer, \& Lipscombe, 2006; Dalrymple, 2011; Vis, Strandbu, Holtan \& Thomas, 2011).

For the social workers, these considerations highlight the importance of the participative work model and an approach of trust in the skills and motivations of the families to solve the problems that led to the removal of the child. Social workers are required to believe, "until proved wrong" (Folgheraiter, 2012, p. 77), that the families are responsible for their own circumstances and that, properly supported, have the ability to come up with the right solutions for themselves. A trusting approach, which allows for the active participation of the 


\section{N Macrothink}

International Journal of Social Work

ISSN 2332-7278

2014, Vol. 1, No. 1

families and the children in decision-making, is also helpful for the social workers. Social workers state that the involvement of the families allows for more open and collaborative professional activity, increases the sense of responsibility of the family, and has a positive effect on the relationship between parents and social workers (Bell, 2001).

The social workers from the Cooperative have re-examined their practices with children in the light of the data and information that has emerged from the research, and let themselves be guided by the discussion on the relational approach to social work which, in Italy, is methodologically based on the work of Folgheraiter $(1998,2011,2012)$. The results of these reflections will be discussed below. Beginning with the task of caring for children, the social workers have re-defined their function from "solvers of problems" to "facilitators of the relationship" with the families. This article describes the methodological guidelines that promote the participation of families of children living in the children's home: collaboration during the arrival and welcoming stage, parental participation in the life of the children's home, shared decision-making practices and participation in a self-help group.

\section{Principles and Responsibilities}

Over the years, social workers working with vulnerable families and children have often needed to confront a situation which may be described as a "collision of values". Faced with the need to make choices, they have had to consider what should be done "in principle" as well as identify the responsibilities of any given specific situation, taking into account the consequences of all possible courses of action. While child protection is often based on absolute principles (Note 2), the long-term consequences of the decisions taken are sometimes not sufficiently taken into account. For example, a mother who has difficulty in taking care of her child, despite "being there for him or her", has the child removed. This particular mother may well lose her remaining capacity to take care of the child, since she is no longer actively involved. The removal of the child, while guaranteeing his or her immediate protection, diminishes parental capability and therefore has a negative impact on the conditions for a possible reunion. The risks inherent in such a course of action are well known and even referred to in legislation (Note 3).

The decision to remove a child for reasons of protection respects both the principle of the best interests of the child and the statutory mandate for care providers. But the temporal dimension and the future consequences of the choices made must also be taken into account. When considering the removal of a child from the family environment, the relationship between methods and objectives becomes a central issue. This is true also for the long-term consequences, the active involvement of the individuals concerned, and the results of removal compared to possible alternative courses of actions, both of prevention and support, which could still be implemented. In the case of removal from the family, and given these underlying premises, what are the specific functions of a children's home?

\section{The Duties of Care: Who is the Children's Home for?}

In the Italian child protection system, children's homes have the formal task of taking care of children and young people who have been removed from their families in cases of significant 
prejudice. A children's home is a social environment where the authority figures or responsible individuals vary according to the organisational model, the professional perspectives of the practitioners and the subjectivity of all those present. The work in the children's home represents a part of the carers' lives that defines their professional identity (Kaneklin \& Orsenigo, 1992). Based on our experience, we do not believe that a children's home, even one based on a family model, can replace the specificity of the family experience, which is characterised by selfless giving, the gratuitousness of its relationships, generativity and the construction of intergenerational ties (Scabini \& Cigoli, 2000; Scabini \& Rossi, 2000).

In order to offer children a family space, the care solution must be something other than the children's home. This would involve a foster family or, in those cases where the natural parents are deemed to be beyond recovery, an adoptive family. In this way, the child can experience a real family environment.

Within such a framework, the children's home social workers need to fulfil an explicitly different social and pedagogic function and to promote anti-oppressive practices (Dominelli, 2002; Dalrymple \& Burke, 2006; Adams, Dominelli, \& Payne, 2009) in order to support children and their parents. When the parents are present, both symbolically and relationally, but are unable to take care of the child and need support in order to regain this ability, the children's home social workers can effectively work alongside them, by caring for the child and assisting the family in re-acquiring the necessary parenting skills for a future reunification.

\section{The Opening-up of Children's Homes to the Families}

Following on from these considerations of the possible functions of children's homes, social workers attempt to identify ways of involving and encouraging participation by the families in the life of the children's home. The forms of participation depend on the institutional and professional approach to child protection. There are two possible orientations:

- one that places practitioners at the centre of the care process

- another that calls for a reciprocal relationship between the different parties involved.

The adoption of one or the other of these two perspectives will have an influence on:

(1) the decision-making processes - are they the responsibility of the practitioners or of all parties involved?

(2) how others are considered - are the families service-users or partners?

(3) the political and welfare orientation - bureaucratic or pluralistic?

In the first case, the protection of the child is defined institutionally by the Court that provides the care organisation with a mandate of responsibility. In order to fulfil this responsibility, the Child Protection Service of the local authority identifies a children's home, defines the specialist actions required and regulates the relationship with the family. The role of the social workers in the children's home is thus to take in the children and take 
responsibility for their day-to-day care as part of a personalised care plan. In this process, the key partner in the work of the children's home is the Child Protection Service. The Service is the referring agency which defines the rules and gives the children's home a mandate to fulfil. The care organisation remains therefore at the centre of the process and regulates the relationship between the care workers and the family; each step in the procedure is characterised by a technical and professional dimension.

Here, there is clearly a risk of hyper-professionalisation of the decision making (Illich, 1977), which does not take into due consideration the expectations and possible actions of the individuals involved. It is also possible, however, to consider well-being not as a dimension defined in a technical way, but rather as a relational concept. This relational dimension may only be identified by bringing into play the inter-subjective perception of everyone involved (Folgheraiter, 2004, 2007). Promoting the protection of children involves considering what is good for the child, beginning with the expectations and opinions of all those involved in the specific situation, including the child (Boylan \& Dalrymple, 2009, 2011, 2013). In order to do this in practice, it is necessary to move from:

(1) the transmission of knowledge to the promotion of capabilities. The child and the parents are participants in the relationship and not objects of an intervention. Practitioners involved in this social educational relationship do not write on blank sheets of paper, or mould the clay according to their own conviction of what is right and good, but rather meet people who have their own history and roots which must be respected, and whose skills are, first and foremost, recognised and valued. This meeting with the other implies listening to their narrative, which inevitably also affects one's own thinking and generates further reflection, created socially as part of the relationship.

(2) the opposition of the "vulnerable person" with the "competent practitioner" to a recognition of the respective knowledge and skills of all involved. Each possesses different skills and each learns something from the other. Even a vulnerable family has the knowledge and expertise of their own life story which even the most experienced social worker cannot possess. The skills are emotional, relational and experiential. They are certainly not professional and, for that reason, unique and irreplaceable (Raineri, 2011). It is therefore necessary, in social educational relationships, for the social worker to recognise these social competencies and help individuals, including the most fragile, to become aware of them.

Consequent to this approach, service providers become members of a network, together with children's home social workers, the young person in care and, where present and interested, the parents and wider family of the child concerned. All those involved contribute their own specific skills, whether technical or experiential, from which reflective reasoning strategies may arise, leading to a change in the situation - a change towards a state of greater well-being. It should be underlined that the presence of the parents, even when they are experiencing great difficulty, is a unique presence which cannot be replaced by any professional figure. Leaving the parents out is an option which is technically possible, but requires very careful 
consideration of the specific nature of the role which is being omitted.

Given the legal framework supplied by the Court, within the latter perspective, all the players involved are required to participate in the decision-making processes and the identification of strategies that will achieve a greater state of well-being for both the child and the family. For this reason we believe it is essential to promote a process of empowerment (Folgheraiter, 2012) which involves the social workers and all the significant people in the lives of the children being brought together in a process of mutual learning.

The social workers' responsibilities in the children's home also include the need to inform, raise awareness, welcome, guide and promote networking among all those concerned with the welfare of the children in care; preconceived strategies are rejected in favour of considering what people are doing to try and improve their living conditions, and valuing the positive aspects which emerge (Folgheraiter, 2004, 2007, 2012).

\subsection{The Role of Children's Home Social Workers as Facilitators}

Initially, the role of children's home social workers with regard to the family is often to protect the children from possible interference by parents or relatives. It is common practice for Italian children's homes themselves to apply for a period of observation and "settling" of the child. This is a time of separation from the family that allows the child to reflect on and come to terms with the events that have led to his or her removal. At other stages of the process, children's home social workers facilitate meetings between the minors and their families and are asked to observe and evaluate the relationship between the parents and their children. On other occasions, encouragement towards reunification between parents and children is required.

The definition of the care plan is often left to the competence of child protection services, possibly in cooperation with children's home social workers. It is during this decision-making phase that the methods of supporting the family, the processes where parents must be involved and the strategies to maintain contact between parents and children are identified. Working with the family is, therefore, the responsibility of child protection social workers.

Our experience of using a participatory approach in the children's home has shown us that, although this way of treating the families can contribute to the protection of the child (especially in situations where it is necessary for the children's home to assume a protective role), it is also possible, in many other situations, both to take in the child and promote the involvement of parents, facilitating the recovery process of their skills, beginning with their participation in the life of the children's home.

Keeping the parents out of the decision-making processes, leaving the responsibility of care entirely to the social workers, and only recognising the competence of professionals in the definition of a plan designed to create a better quality of life for the family, are working mechanisms that create a specific framework. This is a framework where, on the one hand, we have competent social workers who are able to take care of the children and, on the other, parents who labour under the burden of their difficulties and inabilities and who need guidance in order to regain their children, provided that they follow the instructions "on the 
tin".

It is necessary for the social workers to reinterpret their functions as facilitators and to work alongside the family. The sharing of everyday life and the day-to-day care of the child allows the staff of the children's home to construct a significant and unique bond, not only with the children, but also with their families.

\subsection{Networking}

In order to understand the problems that culminate in the removal of a child it is necessary to understand the inter-subjective perception of the individuals involved (Folgheraiter, 2004, 2007; Raineri, 2004). To be able to identify possible responses to these problems, we therefore need to initiate a shared reflection on the part of all those who are motivated and interested in finding a solution to a negative situation.

The relationship promoted by the social worker is a participatory educational relationship starting from the assumption that, given the complexity of the problems of family life, one cannot simply provide prefabricated, undifferentiated or exclusively technical procedures. It is necessary to promote reflective processes that give voice to and integrate both the technical skills of the practitioners and the experiential, emotional and psychological skills of those who have the intention of re-assuming a caring role in the future. The purpose of this network is the well-being of the child and, potentially, also of the family. The possibility of dialogue between the technical competencies of practitioners and the experiential skills of the parents, when integrated, encourages meaningful reflection and facilitates the identification of possible ways to improve the situation.

In this way, we successfully overcome the dichotomy of "the good guys vs. the bad guys", the protective staff vs. the neglectful family, and recognise the limits, boundaries and responsibilities on both sides. The social workers contribute their professional knowledge, but are neither familiar with the history of the child nor what it means to experience that specific situation. They are better able to observe, understand, and approach it with the help of the main players, the child and the family, who, moreover, need to be accompanied in order to regain their mutual positive relationship. For this reason, the parents do not disappear from the scene and, where possible, the families participate with the social workers in the evaluation and planning stages. The involvement of the parents, the young people and any other significant adults who are both present and motivated, becomes therefore a necessary pre-condition for the entire care process.

Promoting the participation of parents in the care process is also beneficial for the social workers involved (Bell, 2001). The experiential skills of the parents help the social workers to learn more about the child or young person with whom they are working. Equally, for the child/young person to see their parents collaborate with social workers allows him/her to open up a relationship with the professional carers with less suspicion.

\section{How Are the Families Involved?}

Family involvement is achieved through the construction of an extended care relationship, the 
promotion of participatory decision-making processes and the organisation of group meetings.

\subsection{The Extended Care Relationship}

The families are involved both during the initial reception of and care planning for the child, and throughout the entire stay of their children in the children's home. This active collaboration becomes possible when parents recognise the children's home as a place that welcomes and looks after their children with affection - a place that guarantees them positive experiences and helps them to grow. If, in addition, there is simultaneous recognition on the part of the social workers of the skills contributed by the parents, the specificity of their actually being the parents, the relationship which was created forcibly and institutionally may be redefined within a context of reciprocity based on trust and recognition (Rossiter, 2011). This partnership and active involvement prevents parents from feeling deprived of their role and allows them to rediscover themselves as parents by participating in the intervention of the social workers who assist them.

\subsection{Participatory Decisional Processes}

Protecting children in difficult circumstances means, above all, promoting experiences of resilience which help them to preserve their own stories, holding together their previous family experiences, preventing the breaking of bonds and ensuring the recognition and preservation of the "good" relationship with their parents and wider family.

Child protection requires an initial acknowledgement that the family, when present and interacting with practitioners, is interested and wishes to retain a caring role even if, as often happens in cases of removal, institutional intervention is necessary for the protection of the child. Nowadays, there is recognition of the theoretical and methodological importance of avoiding fragmentation and opposition among the people present in the lives of the children, whether professionals or family, in order for the child not to be in a position of having to choose sides, and thus having to deal with the inevitable conflicts of loyalty and belonging.

The purpose of working with the families is, first and foremost, to encourage parents to think more deeply and more positively about themselves, taking them from anger and suffering, towards awareness and reflection. The parents need to feel that their views are taken into account and that their skills are recognised, rather than being stigmatised by their failings. An involved parent is a parent who can better take care of the child on his or her return to the family, and who already participates on a day-to-day basis in the educational work, contributing the experiential knowledge of the young person which the social workers do not possess. The most important reason, however, for the participation of the parents in their children's lives is simply the fact that they are their parents, and have the right to be there until a judge says otherwise. As we underlined earlier, social workers can replace them, both practically and symbolically, only for certain functions. Giving greater opportunities to the parents means giving greater resources to the children; it is not just a matter of ethics, but also of substantial support to the child in care. 


\subsection{The Self-Help Group}

Using these considerations as a springboard, the children's home staff launched a self-help group (Steinberg, 1997) for parents of children in the homes or in foster families. The organisation of social events for the parents by the children's home allowed us to observe how these moments of encounter might allow parents to talk to each other without fear of stigma, given that all of them were in a similar situation. The parents themselves have begun to ask if they can meet up more often. This experience provided the momentum for the creation of a self-help group as a meeting and discussion space, a place where they can express their emotions and their pain and find comfort in being together without fear of prejudice. The group has become an empowerment tool.

Self-help groups are voluntary small group structures for mutual aid and the accomplishment of a specific purpose. They are usually formed by peers who have come together for mutual assistance in satisfying a common need, overcoming a common handicap or life-disrupting problem, and bringing about desired social and/or personal change. The initiators and members of such groups perceive that their needs are not, or cannot be, met by or through existing social institutions. Self-help groups emphasize face-to-face social interactions and the assumption of personal responsibility by their members. (Katz, Bender, 1976)

In our experience of the group, parents have initially displayed anger towards social workers and pain at the separation of their children, in many cases considered unjust. Being able to tell their own story has allowed each of them to re-visit, through the eyes of others, their difficulties and fragility, a recognition that has been able to express itself thanks to the suspension of judgement; the difficult situation is shared by all. We have witnessed the emergence of trusting relationships between the members, relationships that have created new motivation and new strength in the way these individuals relate to the outside world.

The dynamics of mutual aid allow parents to rediscover the possibility of saying something important and useful, not only for themselves but also for others. This evident process of re-acquisition of competence leads to a greater confidence in their ability to improve their own image, social role and parental function. The group also allows participants to escape their solitude and build relationships that go beyond the group meeting and give rise to reciprocity in everyday life. "When you're feeling down, you can call someone" says one mother. "It's a group that listens" says another. The listening dimension acts as a new discovery. It is as if, finally, a place has been found free from judgements and evaluations, which is dedicated solely to being able to talk and be understood.

What the social workers and child protection professionals who deal with the families have found is that the parents have acquired greater interpersonal and communication skills, enhanced self-confidence and perhaps even a greater willingness to listen to the arguments of others, without necessarily changing their opposition to the removal. 


\section{Conclusions}

The work of the children's home responds to an institutional mandate - to create a safe environment which is conducive to the growth of the children and young people. In this paper, we have tried to highlight the social mandate which may also be fulfilled by a children's home, especially if managed by a non-profit organisation whose mission is to promote community well-being, social cohesion and active and responsible participation in society. Caring for children and young people and the daily interaction with the world of institutions and of society at large puts the children's home social workers in a privileged position. This is a position which permits recognition of the specificity of all the different actors involved, a comprehension of the complete range of perspectives and an appreciation of the positive aspects which emerge from the meeting of all those present and involved in child protection, whether professionals, family members or volunteers. From this perspective, the children's home social workers, as well as taking in children and caring for them, can stand alongside and assist in the care responsibilities of the family.

Social workers working in children's home can facilitate the creation of connections, enabling communication and information exchange between public services and the family, including technical and experiential knowledge. The adults present, firstly the children's home social workers as "social parents", but also all the other social and family figures, accompany the young people in each phase of development, maintaining their roots and protecting the personal history of the children in care.

The processes activated by the children's home social workers are aimed at creating new relationship spaces, where each personal story, beginning with its current situation, can be located, narrated and acknowledged. The opportunity to tell one's own story is the starting point for any discussion which is not aimed at persecution or social control, and the only one which encourages the participation of individuals in the decisions which affect them and their future lives.

Each person, whether adult or child, holds the truth of their own story and the social workers cannot ignore it and/or reduce it to a stereotypical, artificial construct such as that provided by an exclusively technical analysis. In order not to transform the job of residential social workers into what Illich (1977) defines as a "disabling profession", we must be able to ensure that the children's home acts relationally, recognising the importance of the families' right to participate in the life of the home and the construction of the care plan for the young person in question.

The involvement of the family is the bridge to a "community open to society", which expresses its own political capability and, via its mode of operation, becomes a "joint social enterprise", contributing to the construction of social welfare. Working with the parents implies deciding with them, creating an open children's home that neither judges parents nor makes them feel guilty, but rather becomes a social resource at the service of vulnerable families (neither a substitute nor a source of persecution) promoted by the polis as a support for the primary entity, the family. 


\section{References}

Adams, R., Dominelli, L., \& Payne, M. (Eds). (2009). Critical Practice in Social Work (2nd ed.). Palgrave Macmillan.

Aglietta, E., Bonaga, S., \& Ferrone, D. (2010). "Eravamo come un'isola sperduta...”: l'affidamento narrato in prima persona. In A. R. Favretto \& C. Bernardini (Eds.), Mi presti la tua famiglia? Per una cultura dell'affidamento eterofamiliare per minori (pp. 91-155). Milano: FrancoAngeli.

Bastianoni, P., \& Taurino. (2009). Le comunità per minori. Roma: Carocci.

Bell, M. (2001). Il coinvolgimento della famiglia negli interventi per minori a rischio. Lavoro Sociale, 1(2), 176-187.

Belotti, V., Milani, P., Ius, M., Satta, C., \& Serbati, S. (2012). Crescere fuori famiglia, Venezia: Osservatorio Regionale Politiche Sociali della Regione Veneto.

Bondioli, R., \& Molinari, L. (2005). Minori in affido: perché?. Prospettive Sociali e Sanitarie, 7, 10-14.

Boylan, J., \& Dalrymple, J. (2011). Advocacy, Social Justice and Children's Rights. Practice: Social Work Action, 23(1), 19-30.

Boylan, J., \& Dalrymple, J. (2009). Understanding Advocacy for Children and Young People. New York: Open University Press.

Boylan, J., \& Dalrymple, J. (2013). Effective Advocacy in Social Work. London: Sage.

Buckley, H. (2003). Child Protection Work. Beyond the rhetoric. London: Jessica Kingsley.

Burgheim, T. (2002). The grief of birth parents whose children have been removed: Implications for practice in out of home care. Paper delivered at What works!? Evidence based practice in child and family services (Biennial Conference). Australian Children's Welfare Agencies (ACWA). Sidney, 2-4 September.

Cameron, G., \& Hoy, S. (2003). Stories of mothers and child welfare. Paper presented at the Finding A Fit Conference. Waterloo, Ontario, $27^{\text {th }}$ August.

Carletti, V., \& Pellegrini, M. (2011). Le famiglie affidatarie in rete. Indagine conoscitiva sull'esperienza della Comunità Murialdo in Trentino-Alto Adige. In P. Donati, F. Folgheraiter, \& M. L. Raineri (Eds.), La tutela dei minori. Nuovi scenari relazionali (pp. 291-303). Trento: Erickson.

CRC Group. (2013). I diritti dell'infanzia e dell'adolescenza in Italia. $6^{\circ}$ Rapporto di aggiornamento sul monitoraggio della Convenzione sui diritti dell'infanzia e dell'adolescenza in Italia 2012-2013. [Online] Available: http://www.gruppocrc.net/IMG/pdf/6_rapporto_CRC.pdf (March 5, 2014)

Dalrymple, J. (2011). La voce dei minori: partecipazione e interventi di tutela. In P. Donati, F. Folgheraiter, \& M. L. Raineri (Eds.), La tutela dei minori. Nuovi scenari relazionali (pp. 
291-303). Trento: Erickson.

Dalrymple, J., \& Burke, B. (2006). Anti-oppressive Practice. Social care and the Law. Open University Press.

Dominelli, L. (2002). Anti-oppressive Social Work: Theory and practice. London: Palgrave Macmillan.

Fernández, E. (1996). Significant Harm: Unraveling child protection decisions and substitute care careers of children. Aldreshot: Avebury

Folgheraiter, F. (1998). Teoria e metodologia del servizio sociale. Milano: FrancoAngeli.

Folgheraiter, F. (2004). Relational Social Work. Toward Networking and Societal Practice. London: Jessica Kingsley.

Folgheraiter, F. (2007). Relational Social Work: Principles and Practices. Social Policy and Society, 6(2), 265-274. http://dx.doi.org/10.1017/S1474746406003526

Folgheraiter, F. (2011). Fondamenti di metodologia relazionale. La logica sociale dell'aiuto. Trento: Erickson.

Folgheraiter, F. (2012). The Mystery of Social Work. Trento: Erickson.

Freymond, N. J. (2003). Mother's everyday realities and child placement experiences, partnerships for children and families project. Wilfred Laurier University. Paper presented at the Finding A Fit Conference. Waterloo, Ontario, $27^{\text {th }}$ August.

Gregorio, D., \& Tomisich, M. (Eds.) (2007). Tra famiglia e servizi: nuove forme di accoglienza dei minori. Milano: FrancoAngeli.

Harries, M. (2008). The experience of parents and families of children and young people in care. Centre for vulnerable children and families. The University of Western Australia. [Online]

Available:

http://library.wnhs.health.wa.gov.au/Documents/63343_Exp\%20of\%20Parents_v3.pdf

(March 5, 2014)

Illich, I., Zola, I., McKnight, J., Caplan, J., \& Shaiken, H. (1977). Disabling Professions. London: Marion Boyars Publ. Ltd.

Kaneklin, C., \& Orsenigo, A. (Eds.) (1992). Il lavoro di comunità. Modalità di lavoro con adolescenti in difficoltà. Roma: NIS.

Katz, A., Bender, E. (1976). The Strength in Us: Self-Help Groups in the Modern World. NY: Franklin-Watts. Cit. In A., Katz. Self-Help and Mutual Aid: An Emerging Social Movement?. Annual Review of Sociology, 7(1981), 129-155.

Ministero del Lavoro e delle Politiche Sociali. (2012). Bambine e bambini temporaneamente fuori dalla famiglia di origine. Affidamenti familiari e collocamenti in comunità al 31 dicembre 2010. Sintesi delle prime risultanze. Roma: Quaderni della ricerca sociale n. $19 / 2012$. 


\section{Macrothink}

International Journal of Social Work ISSN 2332-7278 2014, Vol. 1, No. 1

Morris, K. (2007). Camden FGC Service, an Evaluation of Service Use and Outcomes, Camden.

Morris, K. (2012). Thinking family? The complexities for family engagement in care and protection. British Journal of Social Work, 2, 906-920. http://dx.doi.org/10.1093/bjsw/bcr116

Moyers, S., Farmer, E., \& Lipscombe, J. (2006). Contact with Family Members and its Impact on Adolescents and Their Foster Placements. British Journal of Social Work, 36, 541-559. http://dx.doi.org/10.1093/bjsw/bch270

Patt, S. (2011). L'ascolto dell'esperienza di chi è stato affidato. Prospettive assistenziali, 175, 16-20.

Raineri, M. L. (2004). Il metodo di rete in pratica. Studi di caso nel servizio sociale. Trento: Erickson.

Raineri, M. L. (2011). Il valore delle conoscenze esperienziali. In P. Donati, F. Folgheraiter, \& M. L. Raineri, (Eds.), La tutela dei Minori. Trento: Erickson, 2011.

Rossiter, A. (2011). Unsettled social work: The challenge of Levinas' Ethics. British Journal of Social Work, 41(5), 980-995. http://dx.doi.org/10.1093/bjsw/bcr004

Scabini, E., \& Cigoli, V. (2000). Il famigliare. Legami, simboli e transizioni. Milano: Raffaello Cortina.

Scabini, E., \& Rossi, G. (Eds.) (2000). Dono e perdono nelle relazioni familiari e sociali. Milano: Vita e Pensiero.

Shofield, G., Moldestad, B., Hojer, I., Ward, E., Skilbred, D., Young, J., \& Havik T. (2011). Managing loss and a threatened identity: experiences of parents of children growing up in foster care, the perspectives of their social workers and implications for practice. British Journal of Social Work, 41(1), 74-92. http://dx.doi.org/10.1093/bjsw/bcq073

Steinberg, D. M. (1997). The Mutual-aid Approach to Working with Groups: Helping people help each other. Jason Aronson Inc.

Thomson, M., \& Thorpe, R. (2003). Powerful partnership in social work: group work with parents of children in care. Australian Social Work, 57(1), 49-60.

Vis, S. A., Strandbu, A., Holtan, A., \& Thomas, N. (2011). Participation and health - a research of child participation in planning and decision making. Child and Family Social Work, 16, 325-335. http://dx.doi.org/10.1111/j.1365-2206.2010.00743.x

Walker, J. (2011). The relevance of shame in child protection work. Journal of Social Work Practice. http://dx.doi.org/10.1080/02650533.2011.560660

\section{Note}

Note 1. The Working Group for the Convention on the Rights of the Child (CRC Group) is a 


\section{Macrothink}

International Journal of Social Work

ISSN 2332-7278 2014, Vol. 1, No. 1

network of Italian associations that work to ensure a system of independent monitoring of the implementation of the UNCRC and the UN Committee's concluding observations in Italy.

Note 2. The best interests of the child is a key principle set out in Article 3 of the UNCRC which states that "In all actions concerning the child, whether undertaken by public or private social welfare institution, courts of law, administrative authorities or legislative bodies, the best interests of the child shall be the primary consideration".

Note 3. Italian National Law 149/01, amending the previous law, 184/83, emphasised the importance of fostering projects in non-related families being temporary, and established a probationary period of two years.

\section{Copyright Disclaimer}

Copyright reserved by the author(s).

This article is an open-access article distributed under the terms and conditions of the Creative Commons Attribution license (http://creativecommons.org/licenses/by/3.0/). 